\title{
A systematic review of the literature on the causes of early school leaving in Africa and Asia
}

Citation for published version (APA):

Morro, M. S. M., Cabus, S. J., De Witte, K., \& Groot, W. (2019). A systematic review of the literature on the causes of early school leaving in Africa and Asia. Review of Education, 7(3), 496-522.

https://doi.org/10.1002/rev3.3134

Document status and date:

Published: 01/10/2019

DOI:

10.1002/rev3.3134

Document Version:

Publisher's PDF, also known as Version of record

Document license:

Taverne

Please check the document version of this publication:

- A submitted manuscript is the version of the article upon submission and before peer-review. There can be important differences between the submitted version and the official published version of record.

People interested in the research are advised to contact the author for the final version of the publication, or visit the DOI to the publisher's website.

- The final author version and the galley proof are versions of the publication after peer review.

- The final published version features the final layout of the paper including the volume, issue and page numbers.

Link to publication

\footnotetext{
General rights rights.

- You may freely distribute the URL identifying the publication in the public portal. please follow below link for the End User Agreement:

www.umlib.nl/taverne-license

Take down policy

If you believe that this document breaches copyright please contact us at:

repository@maastrichtuniversity.nl

providing details and we will investigate your claim.
}

Copyright and moral rights for the publications made accessible in the public portal are retained by the authors and/or other copyright owners and it is a condition of accessing publications that users recognise and abide by the legal requirements associated with these

- Users may download and print one copy of any publication from the public portal for the purpose of private study or research.

- You may not further distribute the material or use it for any profit-making activity or commercial gain

If the publication is distributed under the terms of Article $25 \mathrm{fa}$ of the Dutch Copyright Act, indicated by the "Taverne" license above, 


\title{
A systematic review of the literature on the causes of early school leaving in Africa and Asia
}

\section{Michelle S. M. Momo`, Sofie J. Cabus, Kristof De Witte and Wim Groot}

Department of Humanities and Sciences, Maastricht University, Maastricht, The Netherlands

\begin{abstract}
This paper systematically reviews the literature on the causes of leaving school early in Africa and Asia. Despite the improvement in primary school enrolment in the developing countries by 2015, the persistence of school dropout, however, renders this improvement almost insignificant. This leads to the necessity of observing the prolonged determinants of dropping out from school amid the current global development efforts to improve educational attainment in these countries. For this purpose, we review 43 articles in this study. These articles are peer-reviewed publications on the causes of early school leaving or school dropout in Africa and Asia, from the year 2001 to present (2018). A great number of causes are found to be linked to the reason for leaving school early. However, the most common causes for early school leaving include lack of income, parents' education and employment status, living in a single-parent household, being a illegitimate child, age, region of residence and school performance. Specifically, for Asia, immigration and ethnicity are important factors. This paper recommends that policies to prevent early school leaving require multi-perspective targeting, involving individual, school, community and family. For instance, attention needs to be drawn to the effective trickling down of necessary school provisions and other contemporary societal provisions to all communities. There is also need for improved individual and family awareness on the positive impact of education as well as the dangers of certain cultural beliefs.
\end{abstract}

\section{Introduction}

\section{Background}

Since This has caused some difficulty because of the link to particular countries. Please check all rearranged cites and countries carefully. the launch of the Millennium Development Goals (MDG), the universal primary school net enrolment ratio has increased from $84 \%$ in 1999 to approximately 93\% in 2015 (UNESCO, 2015). This indicates a decline in out-of-school children worldwide from 100 million in

This research did not receive any specific grant from funding agencies in the public, commercial, or not-for-profit sectors.

Sections of this manuscript have not been published in other venues.

JEL classification: I21; O15; O53; O55.

${ }^{\star}$ Corresponding author. Michelle S. M. Momo, Department of Humanities and Sciences, Maastricht University, Kapoenstraat 2, 6211 KW Maastricht, The Netherlands. E-mail: michelle.momo@maastrichtuniversity.nl 
2000 to 57 million in 2015. In developing nations, however, more than one in four children entering primary school are likely to drop out (United Nations, 2014). As observed by the United Nations, while children are increasingly obtaining primary education in developing nations, a large number of students drop out of primary and secondary education. Education is a key route to the development of a nation and it is a very vital input in fostering economic growth (Shi et al., 2015). A high dropout rate leaves a good number of people without adequate numeracy, literacy and cognitive skills.

Between 1999 and 2013, there has not been a general improvement in the reduction of the rate of early school leaving. Unfortunately, in primary education the rate was found to be higher in 2013 than in 1999, as illustrated in Figure 1 below. It actually ranged between $32 \%$ and $41 \%$ in Africa and $21 \%$ and $28 \%$ in Asia. Precisely, Figure 1 suggests that during this period the cumulative dropout rate in Africa was lowest in 2001 (32.8\%) and highest in 2007 (40.1\%). In Asia, it was lowest in $2001(22.9 \%)$ and highest in 2005 (28.4\%). The cumulative dropout rate is calculated by subtracting the survival rate from 100 at a given grade, while the survival rate is the percentage of a cohort of pupils enrolled in the first grade of a given educational cycle in a given school year (UNESCO Institute for Statistics, 2009).

This systematic literature review aims to examine the determinants of school dropout in Africa and Asia, to identify why some children are more likely to drop out of school than others, in countries where the economy is less developed. This is important to understand the underlying constraints in improving learning outcomes and grade advancement. Furthermore, understanding the specific factors enhancing early school leaving will contribute to the school dropout literature by shedding light on the problems currently pertinent to developing nations. This is critical for formulating and evaluating public and social policies by identifying intervention targets

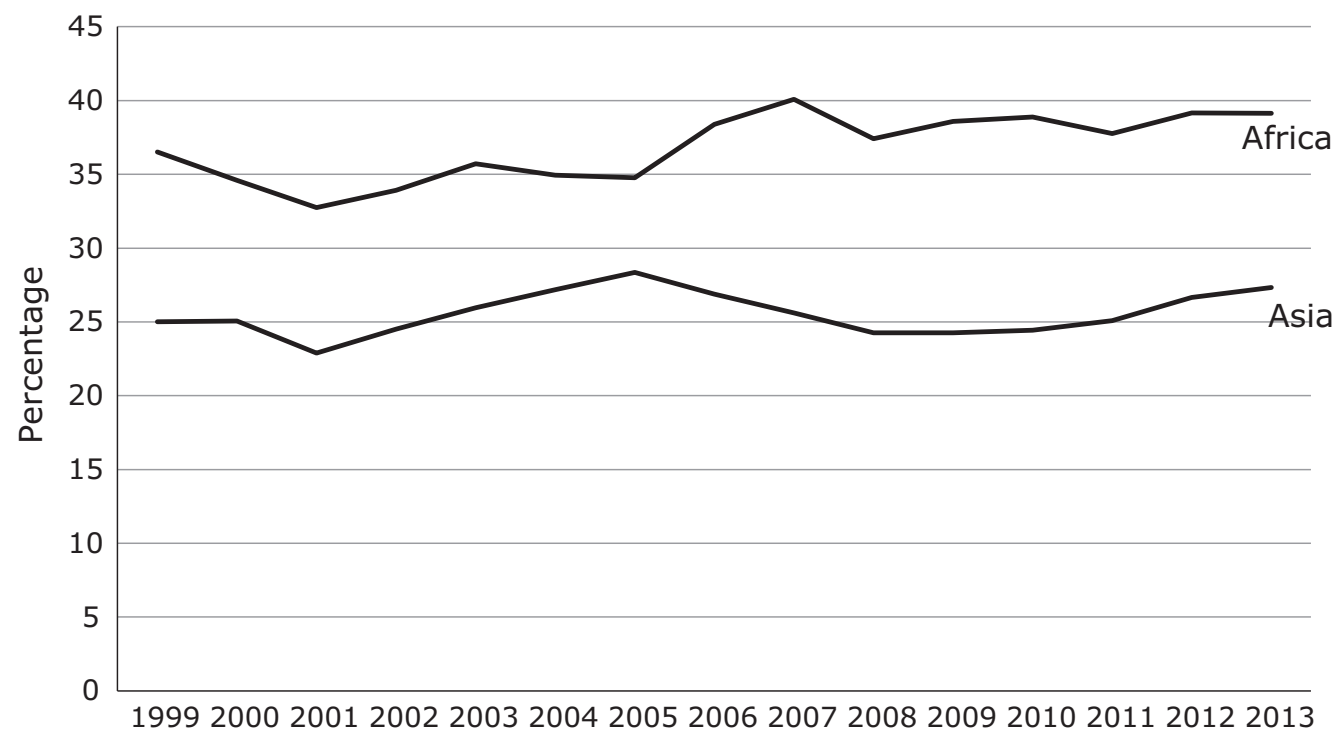

Figure 1. Cumulative dropout rate to the last grade of primary education for Africa and Asia Source: UNESCO Institute for Statistics (2017). 
concerning students, families, institutions, environments and minority or marginalised groups that may have been hidden to policy interventions.

\section{Definition}

'School dropout' or 'early school leaving' is a somewhat ambiguous concept as different countries attribute leaving school early to different years or stages of schooling. Consequently, the term is defined differently by different people (Tukundane et al., 2015). Definitions of school dropout include: a pupil who does not complete the final year of the educational level enrolled in (Braimah \& Oduro-Ofori, 2005); leaving school before completing a given grade in a given school year (Wegner et al., 2008); leaving school before completing primary education, completing primary education but not progressing to secondary grades and leaving school before completing secondary grades (Biddlecom et al., 2008); a pupil who enrols at the beginning of a school year and leaves before the end of the school year and does not enrol elsewhere (UNESCO Institute for Statistics, 2009); a pupil who starts education being over aged and who is prevented from completing owing to repetition (Lewin \& Little, 2011); leaving school before the legal school-leaving age with no formal primary school qualification (Ananga, 2011); a student who is absent from school for at least 1 month, or who fails to take exams, or who is absent in the next year at the school (Manandhar \& Sthapit, 2012); leaving school before completing at least the final secondary grade (Mahlomaholo, 2012); no transition from primary or secondary school to higher education to obtain formal work qualifications (Tukundane et al., 2015); and a student who enrols into formal school but never completes or graduates with his/her cohorts and never re-enrols into another school (Christian, 2015). We therefore acknowledge that there may be differences in the methods of calculation and classifications of early school leavers in the different countries (Lamb \& Markussen, 2011).

\section{Theoretical framework}

Early school leaving is considered as the last stage of a process of disengagement from school which occurs over time (Finn, 1989). These young people who leave school early are mostly from the disadvantaged background in the society (Lamb \& Markussen, 2011). The process that results in withdrawal from school encompasses the outcome of the interactions within and between an individual and the surrounding environment (adapted from Bronfenbrenner (1977)'s ecological framework of human development). Bronfenbrenner (1977) assumed that understanding the reasons for leaving school early is equivalent to studying pupils' relations to one another and to their physical environment, thus the appellation 'ecological'. In the school dropout setting, there are three levels of this environment. These are family, school and the community, respectively, in terms of their closeness to the student (Rumberger, 1995; Abuya et al., 2013). Thus, understanding the reasons for leaving school early evolves around the profound understanding of characteristics and relationships of students and their family, school and community (Abuya et al., 2013). By implication, dropout 
factors comprise four categories (or 'levels'), namely: the student (individual) level, the family level, the school level and the community level. Below, each category is discussed in more depth.

\section{Individual characteristics}

In understanding and explaining the process of dropout, the concepts of emotional, behavioural and cognitive engagement of students are central (Wang \& Fredricks, 2014). This is because they together capture thought, words and action of students that determine their engagement in school. Additionally, the outcome of the interactions of students with their environment can substantially vary with respect to their contexts and characteristics (Bronfenbrenner, 1979). A student is emotionally engaged if he/she has the feeling of being a member of the school, enjoys learning and sees the success from the learning outcome as valuable in life (Finn, 1989). Behavioural engagement is when a student participates in the academic activities (Fredricks et al., 2004). Cognitive engagement, as defined by Pintrich and De Groot (1990), refers to learning out of self-regulation. According to Morrison et al. (2002), school disengagement has numerous elements including negative peer influence, disobedience, truancy and consequent dropout. Newcomb et al. (2002) suggest that illicit drug, alcohol and tobacco use by youths is one of the problem behaviours, and that this has a unique and consistent relationship with dropout.

Other effects like poor school performance, no educational aspirations and exam failure can stem from the inability to emotionally, behaviourally and cognitively engage in school (Ream \& Rumberger, 2008; Skinner \& Pitzer, 2012). Many other reasons pertaining to pupils and students have been enlisted in the literature, some of which include over age, late school entry, gender, illness, exam failure, preference for wage labour, grade repetition and poor nutritional status (Lloyd et al., 2000; AloiseYoung, 2002; Brown, 2010). Girls have been found to drop out of school more than boys ( $49 \%$ for boys as compared with $66 \%$ for girls) in Pakistan (Holmes, 2003). In 2010 in Pakistan, the results of Farid-ul-Hasnain and Krantz showed 51\% dropout rate for girls and $43 \%$ for boys. In Nepal, however, the study of Manandhar and Sthapit (2012) found $5.87 \%$ dropout rate for girls and $6.14 \%$ dropout rate for boys.

The study of Smits and Huisman (2013) found dropout rates for 15 year-olds to be $65 \%$ for girls and $26 \%$ for boys in Yemen, $54 \%$ for girls and $43 \%$ for boys in Morocco, $50 \%$ for girls and $49 \%$ for boys in Syria, 33\% for girls and 23\% for boys in Algeria, and $22 \%$ for girls and $18 \%$ for boys in Egypt. Equally in India, Siddhu (2011) found more girls $(26 \%)$ than boys $(11.5 \%)$ dropping out from school. In the context of the developing countries, the gender effect on school continuity is significant because there is in some areas the prevalence of certain cultural beliefs among which is the preference for one group of children, girls in most cases, to stay at home to do household work or get married while boys can go to school.

\section{Family characteristics}

According to Brown (2010), a greater percentage of the evidence as to why pupils and students regardless of gender leave school early has to do with difficult economic 
circumstances and the inability of families to invest in the education of their children. In other words, Diyu (2001) stated that most of the dropouts or children at risk of dropping out in developing countries are from less well-off families. This is a main characteristic of families of dropouts, alongside the size of the family, migration, family crisis, lack of family support and supervision with school work, and the education of the parents (Chernichovsky, 1985; Guryan, 2004; Thomas et al., 2004).

Parents' education and their influence on school discontinuity are rather contextual and different in some cases in the sense that they are dependent on the parent and gender of the child involved (Holmes, 2003). Other relevant family characteristics are religion and ethnicity. It is believed that in West Africa, most of the dropouts and unenrolled children come from predominantly Islamic groups (Bah-Lalya, 2015). Bah-Lalya (2015) asserted that this can be explained by the fact that traditional Islamic education is more widespread in rural African areas as compared with urban areas, while secular schools are distributed sparsely. Additionally, studies are done in the Arabic or local languages in the Islamic schools but in the secular school, studies are done in French or English. Students find it difficult to continue schooling at a level where the language of instruction is different from their mother tongue. The problems of religion and ethnicity in the realm of education stem from both beliefs and language, especially in areas of concentrated minority subpopulations ( $\mathrm{Lu}$ et al., 2016).

\section{School characteristics}

Some studies highlight school characteristics like school size and school quality, meanwhile others point at the experiences of students in school (Fortin et al., 2013). In terms of school size, children were found to drop out more in large schools than in small schools (Werblow \& Duesbery, 2009). Quality-wise, students stay longer in high-quality schools than in low-quality schools (Hanushek et al., 2008). As suggested in Fortin et al. (2013), the climate of the classroom under which students study and the quality of the relationship they maintain with their teachers and peers are vital for their perseverance and achievement. It also plays an important role in their well-being emotionally and socially (Fredriksen \& Rhodes, 2004).

Therefore, conflicts and negative attitudes of teachers and peers, lack of classroom cooperation and order, and limited academic support are some of the trajectories linked to early school leaving (Dorman et al., 1997; Anderson et al., 2004). Apart from the relationship with teachers, teacher absenteeism is another way to demotivate students and develop a negative perception towards the academic environment (Diyu, 2001). Another school characteristic detrimental to school completion is the distance to school (Abuya et al., 2013). Lloyd, Mete and Sathar (2005) found that with the problem of distance, students waste much time commuting to school and therefore become exhausted.

\section{Community characteristics}

Rural areas are said to harbour more dropouts and unschooled children than urban areas because poverty and hardship are more prevalent in those areas, coupled with 
longer distances to school (Bah-Lalya, 2015). Other characteristics include the level of community development and the distance to local economic activities and urban centres (Abuya et al., 2013). Tansel (2002) stated that school dropout is also influenced by the predominant activity carried out in a community. That is, in areas with industrial activities parents tend to educate their children to higher levels than where agriculture is predominant. Communities having low social security experience high dropout rates (Levy, 1971). Similar to insecurity, Staff and Kreager (2008) added that communities with high rates of anti-social behaviour and violence are prone to high dropout rates. There is also the claim that communities that provide employment opportunities help to increase the school incompletion rate (Tansel, 2002). The kind of school in the community plays a role in keeping children in school (Rumberger, 1995), for instance, attending a religious school compared with attending a public school. The findings of Rumberger (1995) showed that this was possible with non-Catholic religious schools because there, the students have more transfer alternatives. Rumberger (1995) also mentions the effect on school completion of the relationship maintained by students with their peers.

Generally, dropout causes can be pull, push, or falling out factors as described by Doll, Eslami and Walters (2013). Pull factors pull students to the point of leaving school, usually in the form of needs and wants external to the school. Push factors are internal to the school, which push students away, and falling out factors neither arise from being pushed out nor owing to wants or needs (Doll et al., 2013). For the purpose of discussion in this article, barriers to school discontinuity (school dropout causes) will be identified through the wide range of reasons why students leave school early, from differentiable categories. This is to provide a platform for identifying appropriate intervention strategies against factors that could be altered.

\section{Method}

\section{Information sources and eligibility criteria}

Five electronic databases (ERIC, PsycINFO, EconLit, SocINDEX and Google Scholar) are searched. The search is limited to peer-reviewed publications from 2001 to 2016 to access the most recent articles at the time of writing (2018). It is also limited to work done on African and Asian countries for primary and secondary levels of education. The keywords used during the search include: 'school dropout', 'early school leaving', 'determinants of school dropout' and 'determinants of school attainment'. The initial search of ERIC, limiting the search to 'foreign' articles so as to eliminate articles written about early school leaving in the USA, yielded 598 articles. Filtering through to identify non-English articles and those that were not done on Africa and Asia, as well as not focused on why students leave school early led to the exclusion of 572 articles. Twenty-six papers were thus considered. We acknowledge that the elimination of non-English articles may lead to the omission of key reports which could have influenced the conclusions drawn. 


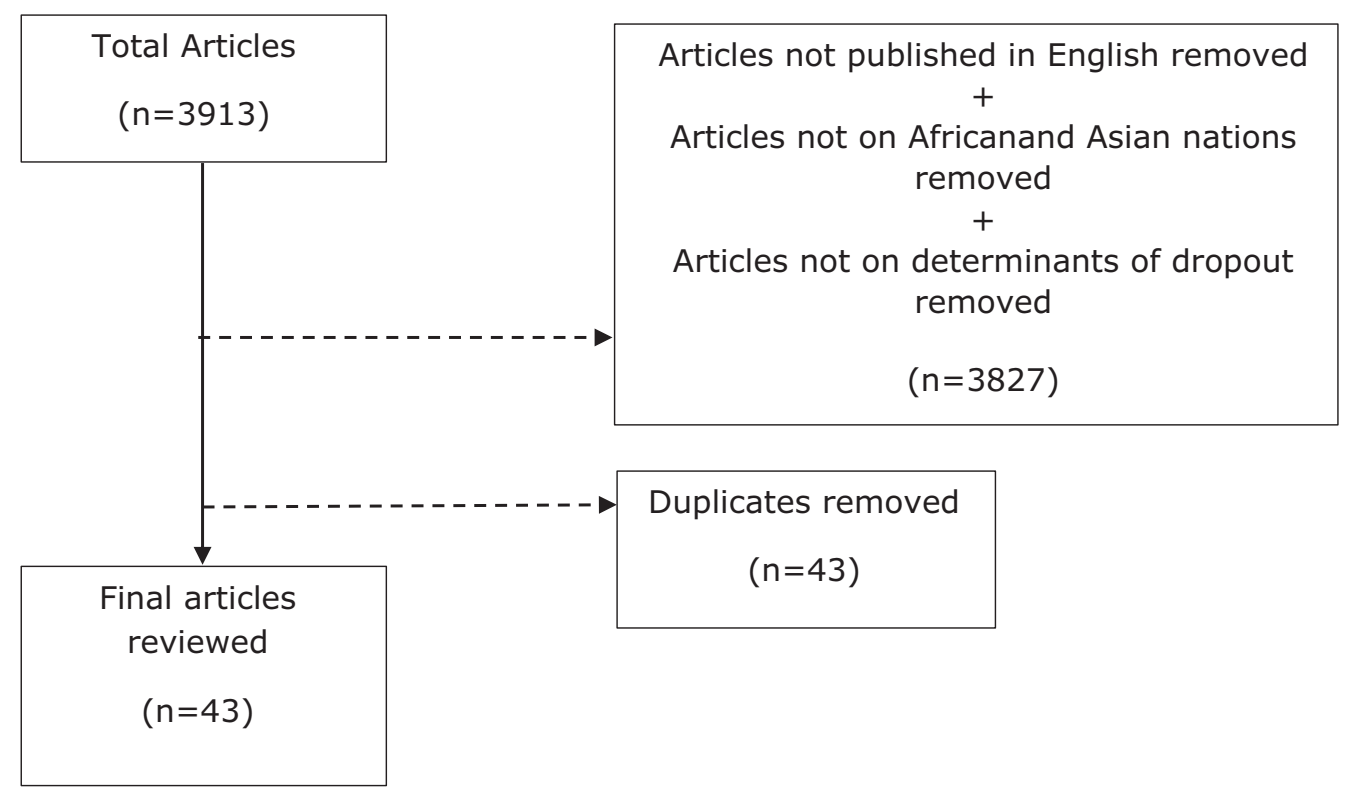

Figure 2. Flowchart of articles reviewed

From PsycINFO, EconLit and SocINDEX, the initial search of the English academic journals yielded a total of 1906 articles. Of these, 25 papers were retained after screening for Africa and Asia nations and causes of leaving school. Screening for journal duplication resulted in six papers eligible for consideration. Google Scholar provided 1409 search results, which were reduced to 35 after initial screening for criteria, and a total of 11 articles retained after duplicates were removed. This gave a final amount of 43 articles for the study, as indicated in Figure 2 that follows;

\section{The data types and analyses included in the review}

The data used in the quantitative and mixed studies include retrospective, two-wave prospective and longitudinal data. These were obtained from school documents, national and international organisations, questionnaires, focus-group discussion and interviews. The studies with retrospective data applied logistic regression, descriptive statistics, analysis of variance, or linear regression. Two-wave prospective data studies mostly applied a logistic model or probit model. The longitudinal studies used logistic regression and survival analysis methods such as the discrete-time logit model and the Cox regression model. Narratives of participants' responses were used to analyse the data in the qualitative studies. The qualitative studies on the one hand, are important in this work as they enable research to get more in-depth information on the needs, desires, problems and circumstances of the subjects. The quantitative data on the other hand, enable access to a greater sample size and thus get access to as much general, though not in-depth, issues as compared with the qualitative data. The causes of early school leaving are similar in the various types of studies and the effects relate to Asian and African countries similarly. Section 4 summarises the results derived from the review. 
Table 1. Significant determinants of early school leaving

\begin{tabular}{|c|c|c|}
\hline Factor & Influence & Study \\
\hline \multicolumn{3}{|l|}{ Student-related } \\
\hline \multirow[t]{2}{*}{ Advancement in age } & Positive & $\begin{array}{l}\text { Biddlecom et al. (2008); Farid-ul-Hasnain } \\
\text { \& Krantz (2010); Flisher et al. (2010); } \\
\text { Siddhu (2011); Korinek \& Punpuing } \\
\text { (2012); Yi et al. (2012); Sabates et al. } \\
\text { (2013); Smits \& Huisman (2013); } \\
\text { Zuilkowski et al. (2016) }\end{array}$ \\
\hline & Negative & Zhao \& Glewwe (2010) \\
\hline Pre-marital sex & Positive & Biddlecom et al. (2008) \\
\hline Late school entry & Positive & $\begin{array}{l}\text { No et al. (2012); Sabates et al. (2013); } \\
\text { No et al. (2016) }\end{array}$ \\
\hline Absenteeism/irregular attendance & Positive & $\begin{array}{l}\text { Flisher et al. (2010); Siddhu (2011); } \\
\text { Sabates et al. (2013); No et al. (2016) }\end{array}$ \\
\hline Grade repetition & Positive & Sabates et al. (2013); No et al. (2016) \\
\hline Poor academic performance & Positive & $\begin{array}{l}\text { Ud Din et al. (2011); No et al. (2012); } \\
\text { Yi et al. (2012); Sabates et al. (2013); } \\
\text { No et al. (2016); Zuilkowski et al. (2016) }\end{array}$ \\
\hline Exam failure & Positive & $\begin{array}{l}\text { Ud Din et al. (2011); Mzuza, Yudong \& } \\
\text { Kapute (2014); Wudu (2015); } \\
\text { Zuilkowski et al. (2016) }\end{array}$ \\
\hline Substance use & Positive & Flisher et al. (2010) \\
\hline Lack of better nourishment & Positive & $\begin{array}{l}\text { Zhao \& Glewwe (2010); Sabates et al. } \\
\text { (2013) }\end{array}$ \\
\hline Not interested & Positive & $\begin{array}{l}\text { Siddhu (2011); Ud Din et al. (2011); } \\
\text { Wudu (2015); No et al. (2016) }\end{array}$ \\
\hline Early marriage & Positive & Farid-ul-Hasnain \& Krantz (2010) \\
\hline Not socialising with other students & Positive & No et al. (2012); No et al. (2016) \\
\hline Lack of self-esteem & Positive & No et al. (2012); No et al. (2016) \\
\hline Preschool or unofficial enrolment & Positive & No et al. (2016) \\
\hline Pregnancy & Positive & Lloyd et al. (2009) \\
\hline Truancy & Positive & Wudu (2015) \\
\hline Disability/illness & Positive & $\begin{array}{l}\text { Yi et al. (2012); Sabates et al. (2013); } \\
\text { Wudu (2015) }\end{array}$ \\
\hline Recently finished primary education & Positive & Huisman \& Smits (2015) \\
\hline \multicolumn{3}{|l|}{ Family-related } \\
\hline Family is an immigrant household & Positive & $\begin{array}{l}\text { Farid-ul-Hasnain \& Krantz (2010); } \\
\text { Korinek \& Punpuing (2012); Cemalcilar } \\
\text { \& Goksen (2014) }\end{array}$ \\
\hline Unawareness of importance of education & Positive & $\begin{array}{l}\text { Ud Din et al. (2011); Banik \& Neogi } \\
\text { (2015); Cemalcilar \& Goksen (2014) }\end{array}$ \\
\hline Family disputes & Positive & Wudu (2015) \\
\hline Family member ill/disabled/elderly & Positive & Wudu (2015) \\
\hline Father's education & Negative & $\begin{array}{l}\text { Biddlecom et al. (2008); Siddhu (2011); } \\
\text { Ud Din et al. (2011); Korinek \& } \\
\text { Punpuing (2012); No et al. (2012); } \\
\text { Yi et al. (2012); Shahidul (2013); Smits } \\
\text { \& Huisman (2013); Huisman \& Smits } \\
\text { (2015); Zuilkowski et al. (2016) }\end{array}$ \\
\hline
\end{tabular}


Table 1. (Continued)

\begin{tabular}{|c|c|c|}
\hline Factor & Influence & Study \\
\hline Mother's education & Negative & $\begin{array}{l}\text { Biddlecom et al. (2008); Lloyd et al. } \\
\text { (2009); Zhao \& Glewwe (2010); Siddhu } \\
\text { (2011); Ud Din et al. (2011); No et al. } \\
\text { (2012); Shahidul (2013); Smits \& } \\
\text { Huisman (2013); Cemalcilar \& Goksen } \\
\text { (2014); Huisman \& Smits (2015); } \\
\text { Zuilkowski et al. (2016) }\end{array}$ \\
\hline Father's employment status & Negative & $\begin{array}{l}\text { Korinek \& Punpuing (2012); Shahidul } \\
\text { (2013); Smits \& Huisman (2013); } \\
\text { Cemalcilar \& Goksen (2014); } \\
\text { Huisman \& Smits (2015 }\end{array}$ \\
\hline Mother's employment status & Negative & Sabates et al. (2013); Shahidul (2013) \\
\hline Father's age & Positive & Siddhu (2011) \\
\hline Poverty & Positive & $\begin{array}{l}\text { Biddlecom et al. (2008); Lloyd et al. } \\
\text { (2009); Farid-ul-Hasnain \& Krantz } \\
\text { (2010); Flisher et al. (2010); Zhao \& } \\
\text { Glewwe (2010); Siddhu (2011); Ud Din } \\
\text { et al. (2011); Korinek \& Punpuing } \\
\text { (2012); Yi et al. (2012); Sabates et al. } \\
\text { (2013); Shahidul (2013); Smits \& } \\
\text { Huisman (2013); Banik \& Neogi (2015); } \\
\text { Huisman \& Smits (2015); Wudu (2015); } \\
\text { Zuilkowski et al. (2016) }\end{array}$ \\
\hline Mother had first child under age 18 & Positive & $\begin{array}{l}\text { Smits \& Huisman (2013); } \\
\text { Huisman \& Smits (2015) }\end{array}$ \\
\hline Single father & Positive & $\begin{array}{l}\text { Biddlecom et al. (2008); Flisher et al. } \\
\text { (2010); Korinek \& Punpuing (2012); } \\
\text { No et al. (2012); Smits \& Huisman } \\
\text { (2013); Huisman \& Smits (2015); } \\
\text { No et al. (2016) }\end{array}$ \\
\hline Single mother & Positive & $\begin{array}{l}\text { Flisher et al. (2010); No et al. (2012); } \\
\text { Sabates et al. (2013); Smits \& Huisman } \\
\text { (2013); Huisman \& Smits (2015); } \\
\text { No et al. (2016) }\end{array}$ \\
\hline Not biological child & Positive & $\begin{array}{l}\text { Smits \& Huisman (2013); Huisman \& } \\
\text { Smits (2015) }\end{array}$ \\
\hline Number of siblings & Positive & $\begin{array}{l}\text { Siddhu (2011); Korinek \& Punpuing } \\
\text { (2012); Smits \& Huisman (2013); } \\
\text { Yi et al. (2012); Huisman \& Smits (2015) }\end{array}$ \\
\hline Birth order & Negative & $\begin{array}{l}\text { Smits \& Huisman (2013); Huisman \& } \\
\text { Smits (2015) }\end{array}$ \\
\hline Household debt & Negative & Korinek \& Punpuing (2012) \\
\hline Extended household & Positive & Farid-ul-Hasnain \& Krantz (2010) \\
\hline Extended household with grand parents & Negative & Huisman \& Smits (2015) \\
\hline Lack of parental care & Positive & Yi et al. (2012) \\
\hline \multicolumn{3}{|l|}{ Work } \\
\hline Domestic and agricultural work & Positive & $\begin{array}{l}\text { Sabates et al. (2013); Banik \& Neogi } \\
\text { (2015); Wudu (2015) }\end{array}$ \\
\hline
\end{tabular}


Table 1. (Continued)

\begin{tabular}{|c|c|c|}
\hline Factor & Influence & Study \\
\hline Wage labour & Positive & $\begin{array}{l}\text { Sabates et al. (2013); Cemalcilar \& Goksen } \\
\text { (2014); Wudu (2015) }\end{array}$ \\
\hline \multicolumn{3}{|r|}{ 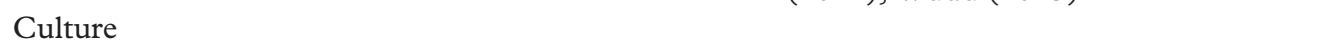 } \\
\hline \multirow[t]{2}{*}{ Gender/female } & Positive & $\begin{array}{l}\text { Siddhu (2011); Shahidul (2013); Smits \& } \\
\text { Huisman (2013); Cemalcilar \& Goksen } \\
\text { (2014); Huisman \& Smits (2015) }\end{array}$ \\
\hline & Negative & $\begin{array}{l}\text { Flisher et al. (2010); Korinek \& Punpuing } \\
\text { (2012); Sabates et al. (2013); Shahidul } \\
\text { (2013) }\end{array}$ \\
\hline Religion/Muslim & Positive & Biddlecom et al. (2008); Siddhu (2011) \\
\hline Ethnicity & Positive & $\begin{array}{l}\text { Lloyd et al. (2009); No et al. (2012); } \\
\text { No et al. (2016) }\end{array}$ \\
\hline \multicolumn{3}{|l|}{ School-related } \\
\hline Inadequate school facilities/quality & Positive & $\begin{array}{l}\text { Zhao \& Glewwe (2010); Cemalcilar \& } \\
\text { Goksen (2014); Huisman \& Smits (2015) }\end{array}$ \\
\hline Unskilled teachers & Positive & No et al. (2012); Zhao \& Glewwe (2010) \\
\hline Unavailability of teachers & Positive & $\begin{array}{l}\text { Zhao \& Glewwe (2010); No et al. (2012); } \\
\text { Huisman \& Smits (2015) }\end{array}$ \\
\hline Conflict with teacher & Positive & Ud Din et al. (2011); Sabates et al. (2013) \\
\hline Leisure boredom & Positive & Wegner et al. (2008) \\
\hline Inadequate assistance to students & Positive & $\begin{array}{l}\text { Ud Din et al. (2011); Sabates et al. (2013); } \\
\text { Cemalcilar \& Goksen (2014) }\end{array}$ \\
\hline School time not suitable & Positive & Banik \& Neogi (2015) \\
\hline Corporal punishment & Positive & Ud Din et al. (2011) \\
\hline Government versus private school & Positive & Lloyd et al. (2009) \\
\hline \multicolumn{3}{|l|}{ Environment } \\
\hline Bullying & Positive & Alika (2012) \\
\hline Employed adults with white-collar jobs & Negative & $\begin{array}{l}\text { Korinek \& Punpuing (2012); } \\
\text { Huisman \& Smits (2015) }\end{array}$ \\
\hline Average men with higher education & Negative & Smits \& Huisman (2013) \\
\hline Distance to school & Positive & $\begin{array}{l}\text { Zhao \& Glewwe (2010); Siddhu (2011); } \\
\text { Wudu (2015) }\end{array}$ \\
\hline Child dependency ratio & Negative & Sabates et al. (2013) \\
\hline Less developed community & Positive & Lloyd et al. (2009) \\
\hline Teacher resides in community & Negative & Lloyd et al. (2009) \\
\hline National GDP per capita & Negative & Huisman \& Smits (2015) \\
\hline \multicolumn{3}{|l|}{ Region of residence: rural/urban } \\
\hline Rural & Positive & $\begin{array}{l}\text { Biddlecom et al. (2008); Korinek \& } \\
\text { Punpuing (2012); Smits \& Huisman } \\
\text { (2013); Huisman \& Smits (2015); } \\
\text { Wudu (2015) }\end{array}$ \\
\hline
\end{tabular}

Note: These factors are significant at $p<.05$, with most of them significant at $p<.001$.

\section{Results}

\section{Presentation of quantitative, mixed and qualitative studies}

In Table 1 below, the factors that were found to be significant are grouped into seven main categories (family, environment, school, region of residence, work, culture, 
student), the influence (with the positive and negative notations indicating correlational relationship) and the articles in which this was observed. This is done for the quantitative and mixed studies. A positive notation denotes a positive relationship with dropout, that is higher values of the variable are associated with higher dropout, while a negative notation refers to an inverse relationship with dropout.

Supplementary tables are presented separately, as an online appendix (online only -for access, see Supporting Information at the end of the paper). They are numbered as Table S1-S3 for quantitative studies, mixed studies and qualitative studies respectively. In these tables, we include the general determinants (both significant and non-significant) of early school leaving in Africa and Asia.

\section{Importance of the significant factors relating to early school leaving}

We note in Table 2 below, the relative importance of these factors with respect to their possible association to early school leaving.

\section{Analysis}

\section{Student}

The age of students as a cause of dropout denotes that as children grow older or as they go further in grade, they are more likely to drop out (Biddlecom et al., 2008; Ampiah \& Adu-Yeboah, 2009; Yi et al., 2012; Smits \& Huisman, 2013; Huisman \& Smits, 2015; Zuilkowski et al., 2016) [Burkina Faso, Ghana, Malawi, Uganda, Ghana, China, Algeria, Egypt, Morocco, Syria, Tunisia, Yemen, 30 developing countries (Bolivia, Colombia, Peru, Benin, Cameroon, Ghana, Guinea, Mali, Nigeria, Senegal, Kenya, Rwanda, Uganda, Congo Brazzaville, Madagascar, Malawi, Mozambique, Namibia, South Africa, Tanzania, Zambia, Algeria, Morocco, Syria, Yemen, Bangladesh, India, Indonesia, Nepal, Philippines), Kenya]. Another effect of age as observed in Manandhar and Sthapit (2012) in Nepal is when a student is 'over age'. Over age students are children older than their classmates of the official age for the grade (Siddhu, 2011). Over age could come as a result of repetition, late school entry, as well as quitting school for some years and returning later (Flisher et al., 2010; No et al., 2016; Zuilkowski et al., 2016) (South Africa, Cambodia, Kenya).

Many school-aged children, as observed by No et al. (2012) in Cambodia, start school late because their parents allow them to become old enough to be able to take care of themselves. This means that they do not enrol in school at the official school enrolment age but rather at ages older than the official age, when their parents think it is safe for them to go to school. The negative effect from over age has been shown to increase at higher grade levels (Sabates et al., 2013) (Bangladesh). Completely dropping out of school for over age students may occur because of the influence of other over age dropouts, and school disassociation owing to alienation from younger classmates (Flisher et al., 2010) (South Africa).

Underage (unofficial enrolment) is a strong causative factor of dropout (No et al., 2016) (Cambodia). They explain that parents prefer to send their children to school once they are 5 years old regardless of the official school enrolment age because they 
Table 2. Importance of the significant factors relating to early school leaving

Factors Conditions susceptible to arise

Advancement in age

Immigrant household

Poverty

Early marriage

Single parent

Rural residence

Few adults with white-collar jobs

Grade repetition

Late school entry
Feeling of alienation from a group of students (younger students in this case), attachment to the wrong group of students (for instance, other older students who also feel detached from school or who may have dropped out from school) (Flisher et al., 2010)

Social discomfort in being older than classmates (Siddhu, 2011)

Financial constraints from physical separation of children from parents, limitations in accessing school facilities, discrimination, cultural adaptation difficulties (Korinek \& Punpuing, 2012)

Difficulties adapting to foreign language (Cemalcilar \& Goksen, 2014)

Children pressurised to look for means to contribute to the family income (Farid-ul-Hasnain \& Krantz, 2010; Banik \& Neogi, 2015)

Males more likely to be pressurised to contribute to family income (Flisher et al., 2010)

Under-nutrition, poor health (Siddhu, 2011)

Irregular school attendance from being sent home for fees (Zuilkowski et al., 2016)

Risk of unwanted pregnancy for girls (Zuilkowski et al., 2016)

Limitation of ability to purchase educational materials (Zhao \& Glewwe, 2010; Huisman \& Smits, 2015; Wudu, 2015)

Devote time to household work and childcare because of social and cultural opinions (Flisher et al., 2010)

Financial difficulties (Flisher et al., 2010)

Being required to take up house work in replacement of missing parent (Smits \& Huisman, 2013)

Not open to better schooling opportunities and likely obliged to do wage labour (No et al., 2012)

Spend time helping at home (No et al., 2016)

Lack of schools labour market opportunities (Korinek \& Punpuing, 2012; Smits \& Huisman, 2013)

Weak influence of modern values (Smits \& Huisman, 2013)

Absence of future employment possibility guarantee (Korinek \& Punpuing, 2012)

Age-in-grade inappropriateness and over age alienation (Sabates et al., 2013)

Reduction of parental investment on education (No et al., 2016)

Feeling of age-in-grade inappropriateness and over age alienation (Sabates et al., 2013)

Develops less interest and preference for opportunity cost of schooling (No et al., 2016) 
Table 2. (Continued)

Factors
Preschool or unofficial enrolment
Parental unawareness of importance
of education
Gender/female

Number of siblings

Birth order

Religion/Muslim

Poor academic performance

Not interested

Less educated father

Less educated mother

Disability/illness

Lack of better nourishment

Long distance to school

Inadequate school facilities/quality

Unskilled teachers

Unavailability of teachers

Not socialising with other students

Lack of self-esteem
Conditions susceptible to arise

Self-alienation from officially enrolled students (No et al., 2016)

Determines whether children stay in school or not, unable to provide academic support to children

Social and cultural beliefs that females do not need education, rather marriage (Siddhu, 2011; Sabates et al., 2013; Smits \& Huisman, 2013)

Face high social risk and limited job opportunities

(Cemalcilar \& Goksen, 2014)

Decision on not educating some school-age children owing to financial difficulties (Siddhu, 2011; Smits \& Huisman, 2013)

Preference given to older born (Smits \& Huisman, 2013)

More restrictions for females in public (Siddhu, 2011)

Feeling deprived, discouraged, alienated from the system of education (Yi et al., 2012)

Corporal punishment (Zuilkowski et al., 2016)

Reduces parental investment in education (No et al., 2012; No et al., 2016)

Develop preference for wage labour (Sabates et al., 2013)

Unable to provide assistance to children on school work

(Biddlecom et al., 2008; No et al., 2012; Huisman \& Smits, 2015)

Unable to provide assistance to children on school work

(Biddlecom et al., 2008; Zhao \& Glewwe, 2010;

No et al., 2012; Cemalcilar \& Goksen, 2014;

Huisman \& Smits, 2015; Zuilkowski et al., 2016)

Probability of being excluded from the educational system

(Sabates et al., 2013)

Irregular attendance (Wudu, 2015)

May jeopardise educational access and educational attainment (Sabates et al., 2013)

Insecurity for girls (Siddhu, 2011)

Community places less value on education (Zhao \& Glewwe, 2010)

Reduces student learning (Zhao \& Glewwe, 2010;

Cemalcilar \& Goksen, 2014)

Impact less knowledge in students (Zhao \& Glewwe, 2010)

Reduces student learning (Zhao \& Glewwe, 2010;

No et al., 2012)

High work load for teachers thereby reducing their quality teaching (No et al., 2012)

Lack of motivation by finding schooling experience boring, not enjoyable and not fear-free (No et al., 2012; No et al., 2016)

Low academic performance (No et al., 2012; No et al., 2016) 
Table 2. (Continued)

\begin{tabular}{lc}
\hline Factors & Conditions susceptible to arise \\
\hline Ethnicity & Speak local languages, thus have difficulties with official \\
& language at school, poor academic performance \\
& (No et al., 2012; No et al., 2016) \\
Absenteeism/irregular attendance & Poor performance and achievement (Sabates et al., 2013; \\
& No et al., 2016; Zuilkowski et al., 2016) \\
Domestic and agricultural work & Irregular attendance (Banik \& Neogi, 2015) \\
Unawareness of importance & Parents prefer to send children to do wage labour, farm \\
of education & and domestic work (Banik \& Neogi, 2015) \\
& Negatively affects investment on education (Cemalcilar \& \\
School time not suitable & Goksen, 2014) \\
Pre-marital sex & Irregular attendance (Banik \& Neogi, 2015) \\
& Promise of marriage that could hasten school dropout, \\
Substance/drug use & unwanted pregnancy (Biddlecom et al., 2008) \\
Father's employment status & Psychopathology (Flisher et al., 2010) \\
& Children obliged to work and contribute to family income \\
Truancy & (Cemalcilar \& Goksen, 2014) \\
Family member disabled/ill & Less interested in schooling (Wudu, 2015) \\
& Obliged to get employment to cater for sick or disabled \\
parent (Yi et al., 2012) & Absenteeism to cater for ill family member (Wudu, 2015) \\
Exam failure & Negative attitude towards school (Mzuza, Yudong \& \\
Leisure boredom & Kapute, 2014; Wudu, 2015; Zuilkowski et al., 2016) \\
(no extracurricular sport & Perceive school as being a boring place (Wegner et al., \\
and leisure activities at school) & 2008) \\
Work & Absenteeism (Sabates et al., 2013) \\
Inadequate assistance to students & Poor academic performance (Yi et al., 2012; Sabates et al., \\
& 2013; Cemalcilar \& Goksen, 2014) \\
& School absenteeism (Sabates et al., 2013) \\
\hline & \\
&
\end{tabular}

are more troublesome when they stay at home. With regards to irregular attendance and absenteeism, the more students are absent from school the higher the odds of leaving school (Flisher et al., 2010; Sabates et al., 2013; Tas, Bora, Selvitopu \& Demirkaya, 2013; No et al., 2016) (South Africa, Bangladesh, Turkey, Cambodia). Several other reasons for absenting from school is due to lack of interest in schooling, exam failure, early marriage, pregnancy, illness, truancy, pre-marital sex, lack of selfesteem, not being sociable, poor academic performance, grade repetition and substance use (Biddlecom et al., 2008; Lloyd, Mete \& Grant, 2009; Farid-ul-Hasnain \& Krantz, 2010; Yi et al., 2012; Sabates et al., 2013; Tas et al., 2013; Igboanusi, 2014; Polat, 2014; Wudu, 2015; No et al., 2016; Zuilkowski et al., 2016) (Ghana, Burkina Faso, Malawi, Uganda, Pakistan, Pakistan, China, Bangladesh, Turkey, Gambia, Turkey, Ethiopia, Cambodia, Kenya).

Good student-to-student relationships help students stay in school. Sometimes this relationship is not cultivated because of fear, insecurity, boredom and intimidation (No et al., 2012; Abuya et al., 2013; Sahin et al., 2016) (Cambodia, Kenya, Turkey). In some cases, students do not willingly pull out but do so because of their 
parents. For example, No et al. (2016) (Cambodia) explained that while high ranking students continue to receive investment from their parents because of the prospect of future economic benefits, poor performing students tend to be considered as nonproductive and will not obtain significant returns. Thus, their parents do not invest in them. Disability is a disadvantage as children are linked to educational exclusion because their guardians consider them as not having potential (Sabates et al., 2013) (Bangladesh). School dropout is also frequent among students who just completed primary school (Huisman \& Smits, 2015) (30 developing countries). Once children complete primary school some of them decide to leave at that stage and some are withdrawn by their parents, probably with the notion that further learning is not important.

\section{Work}

During the harvest season, children absent themselves because they have to join their parents in the farms to harvest as well as to sell (Ampiah \& Adu-Yeboah, 2009; Sarker \& Davey, 2009; Ananga, 2011; Abhisek \& Soumendu, 2014; Wudu, 2015) (Ghana, Bangladesh, Ghana, India, Ethiopia). They are also required to work at home sometimes (Mahlomaholo, 2012; Smits \& Huisman, 2013; Abhisek \& Soumendu, 2014; Abuya et al., 2014; Banik \& Neogi, 2015; Wudu, 2015; Sahin et al., 2016) (South Africa, Algeria, Egypt, Morocco, Syria, Tunisia, Yemen, Kenya, India, Ethiopia, Turkey). It is also common for students to be sent to do wage work to support the family financially (Farid-ul-Hasnain \& Krantz, 2010; Flisher et al., 2010; Abuya et al., 2013; Mokibelo, 2014) (Pakistan, South Africa, Kenya, Botswana). Because guardians need to bring up their own children, they sometimes send non-biological children to do wage labour to reduce the financial burden (No et al., 2012) (Cambodia).

Students also stay at home to take care of the sick, disabled or elderly family members (Wudu, 2015) (Ethiopia). In some cases, the youths willingly leave school to join the world of work because they have no interest in studying (Siddhu, 2011; Mahlomaholo, 2012; Tukundane et al., 2014) (India, South Africa, Uganda). Sabates et al. (2013) note that students spend more time working rather than learning because their parents are not educated and do not see the leverage in letting children learn more. In this case, they do not receive parental assistance on school work. The pressure to do housework is felt more by the girls (Farid-ul-Hasnain \& Krantz, 2010; Manandhar \& Sthapit, 2012; Cemalcilar \& Gokşen, 2014) (Pakistan, Nepal, Turkey).

\section{Family}

Shahidul (2013) demonstrated how parental participation in household decision making affects their child's schooling in Bangladesh. Proxies to participation are education and income level. In other words, the parent with the highest level of education and who earns more money has more of the bargaining power in decision making. Differences lie at the level of the child's gender, where preference is given to the male child. Besides this preference, the effect is more prevalent among selfemployed parents than among parents who are in paid employment (Shahidul, 
2013). However, it was also shown that educated mothers show no preference and consider the education of both genders very important (Shahidul, 2013; Cemalcilar \& Goken, 2014) (Bangladesh, Turkey).

Zhao and Glewwe (2010) in China find mother's education significantly impacting the children's years of schooling positively. This finding is consistent with that of Lloyd et al. (2009) in Pakistan. Nevertheless, in most studies, it was found that if the father or the mother did at least have some primary or secondary education, all the children were liable to stay in school, as the parents then better understand the importance of learning (Biddlecom et al., 2008; Siddhu, 2011; Korinek \& Punpuing, 2012; No et al., 2012; Yi et al., 2012; Smits \& Huisman, 2013; Huisman \& Smits, 2015; Sahin et al., 2016; Zuilkowski et al., 2016) (Burkina Faso, Ghana, Malawi, Uganda, India, Thailand, Cambodia, China, Algeria, Egypt, Morocco, Syria, Tunisia, Yemen, 30 developing countries, Turkey, Kenya).

In terms of occupation, children from agricultural households tend to leave school more often, but if the father's occupation is not in agriculture and especially if it is upper non-farm (white collar), children tend to stay in school more often (Smits \& Huisman, 2013; Cemalcilar \& Goken, 2014) (Algeria, Egypt, Morocco, Syria, Tunisia, Yemen, Turkey). Similarly, as suggested in Korinek and Punpuing (2012) (Thailand) school attrition is significantly lower for children whose parents are employed in entrepreneurial, clerical, managerial, sales, professional and service sectors as compared with those with parents employed in agriculture.

Birth order and number of siblings also have significant impact on grade enrolment (Siddhu, 2011; Korinek \& Punpuing, 2012; Yi et al., 2012; Smits \& Huisman, 2013; Abuya et al., 2014; Huisman \& Smits, 2015) (India, Thailand, China, Algeria, Egypt, Morocco, Syria, Tunisia, Yemen, Kenya, 30 developing countries). In decisions regarding entering school, preference is given to earlier born children, as shown in the study by Smits and Huisman (2013) (Algeria, Egypt, Morocco, Syria, Tunisia, Yemen). There are nonetheless other family factors such as single parent, non-biological child, no parental care, aged father, parental migration, family dispute, presence of extended family and when mothers gave birth too young, that facilitate dropout (Biddlecom et al., 2008; Farid-ul-Hasnain \& Krantz, 2010; Ananga, 2011; Siddhu, 2011; Korinek \& Punpuing, 2012; No et al., 2012; Yi et al., 2012; Huisman \& Smits, 2015; Wudu, 2015; No et al., 2016; Sahin et al., 2016; ) (Ghana, Burkina Faso, Malawi, Uganda, Pakistan, Ghana, India, Thailand, Cambodia, China, 30 developing countries, Ethiopia, Cambodia, Turkey). Single-parent households or orphans generally have fewer opportunities or chances to study than children with both parents alive and present. This notion is similar for children living with parents who are not their biological parents, as observed in Nepal by Manandhar and Sthapit (2012). For non-biological children in Cambodia, their guardians in most cases have their own children to send to school and to reduce the financial burden may decide to enrol only their own children (No et al., 2012).

African and Asian countries have a higher rate of households with very low socioeconomic status as opposed to developed countries. For instance, in African and Asian countries it is very common to live in a household without amenities like television, electricity, running water, toilet facilities, computer, telephones, fridge and vehicle (Farid-ul-Hasnain \& Krantz, 2010; Flisher et al., 2010; Smits \& Huisman, 2013) 
(Pakistan, South Africa, Algeria, Egypt, Morocco, Syria, Tunisia, Yemen), which may add to a disadvantaged learning environment. Generally, parents may be willing to send their children to school but cannot do so owing to the inability to pay school fees, buy school materials or provide for children's safety (Biddlecom et al., 2008; Flisher et al., 2010; Zhao \& Glewwe, 2010; Siddhu, 2011; Korinek \& Punpuing, 2012; Yi et al., 2012; Sabates et al., 2013; Shahidul, 2013; Smits \& Huisman, 2013; Polat, 2014; Banik \& Neogi, 2015; Huisman \& Smits, 2015; Zuilkowski et al., 2016) (Ghana, Burkina Faso, Malawi, Uganda, South Africa, China, India, Thailand, China, Bangladesh, Bangladesh, Algeria, Egypt, Morocco, Syria, Tunisia, Yemen, Turkey, 30 developing countries, Kenya).

Some parents lack awareness of the importance of education, leading them to withdraw children from school (Ud Din et al., 2011; Cemalcilar \& Goksen, 2014; Banik $\&$ Neogi, 2015) (Pakistan, Turkey, India). The analysis of Banik and Neogi (2015) in India showed that these parents consider education as a waste of money which may make them go hungry. Dropout is also prevalent among immigrant households, as observed in Pakistan, Thailand and Turkey (Farid-ul-Hasnain \& Krantz, 2010; Korinek \& Punpuing, 2012; Cemalcilar \& Goksen, 2014). According to them, difficulties faced by migrants as a result of migration which hamper the children's schooling include difficulty in adapting to a different culture or ethnic background, absence of citizenship rights, discrimination and marginalization, and foreign language communication difficulty.

\section{Culture}

Cultural restrictions on gender, which are more prevalent in rural areas, show a preference for boys' education than girls ( Biddlecom et al., 2008; Ampiah \& AduYeboah, 2009; Smits \& Huisman, 2013; Abuya et al., 2014; Tukundane et al., 2014; Sahin et al., 2016) (Ghana, Burkina Faso, Malawi, Uganda, Ghana, Algeria, Egypt, Morocco, Syria, Tunisia, Yemen, Kenya, Uganda, Turkey). Since marriage is the ultimate goal for girls in these societies, high education levels are not necessary, so they are being kept close to home (Siddhu, 2011; Sahin et al., 2016) (India, Turkey). In traditional families, marriage is arranged for the girls by the families. Children born in such new homes with a traditional mother who was married off early are negatively affected in the sense that they risk not going to school too. Boys are reckoned to take care of their parents in old age and thus investment on boys is more inclined (Shahidul, 2013; Smits \& Huisman, 2013) (Bangladesh, Algeria, Egypt, Morocco, Syria, Tunisia, Yemen).

Manandhar and Sthapit (2012) observed another form of gender bias in Nepal where more boys are enrolled in private schools than government schools while girls are rather enrolled in government schools. In a private school parents pay admission and examination fees, while this is free in the government school, but the private school is advantageous in that children get more individual care and attention (Manandhar \& Sthapit, 2012). The findings of Korinek and Punpuing (2012) in Thailand revealed that girls are, however, more favoured than boys because they are deemed reliable in providing greater and more certain returns. This is observed in regions where factory production jobs are dominant. 
The problem of ethnicity lies at the level of languages, given that the different ethnic groups may have different local languages. For example, when children study in their local language in the first few years, transitioning to further studies in schools in which the official language is different from what they speak is cumbersome and they tend to perform poorly (Sarker \& Davey, 2009; No et al., 2012; Abhisek \& Soumendu, 2014; Igboanusi, 2014; No et al., 2016;) (Bangladesh, Cambodia, India, Gambia, Cambodia). Being part of a disadvantaged minority as observed in Bangladesh and India is also a factor observed in terms of religion (Sarker \& Davey, 2009; Abhisek \& Soumendu, 2014). In two of such studies carried out in Ghana, Burkina Faso, Malawi, Uganda and India, the minority religion that was noted is Islam (Biddlecom et al., 2008; Siddhu, 2011). Muslim children were seen to drop out more than others and this is even more prevalent among girls.

\section{School}

Wegner et al. (2008) found leisure boredom as one of the quality weakness aspects of schools that make students disconnect themselves to the point of departing in South Africa. Students may feel bored because of lack of recreational, sports and leisure activities for their prosocial development. Other school provisions such as inadequate and low-quality facilities, less qualified teachers and unavailability of teachers deter students from staying in school (Zhao \& Glewwe, 2010; Chung \& Mason, 2012; Abhisek \& Soumendu, 2014; Cemalcilar \& Goken, 2014; Edwards et al., 2014; Huisman \& Smits, 2015) (China, China, India, Turkey, Cambodia, 30 developing countries). In Cambodia, No et al. (2012) showed that trained teachers improve their students' experience and performances as a result of the better and effective methods of teaching that they use. This notion is consistent with the conclusions in the study by Zhao and Glewwe (2010) in China.

However, teaching performance is also affected by the shortage of teaching staff. The few available teachers are usually required to teach in both the morning and afternoon shifts, which leads to exhaustion. This tends to negatively affect the learning experiences and performance of students, and consequently increases the dropout risk (No et al., 2012) (Cambodia). Evidence from Pakistan, Kenya, Turkey and Cambodia also suggests that school work assistance to students tends to enhance their performance (Ud Din et al., 2011; Abuya et al., 2013; Cemalcilar \& Goken, 2014; Edwards et al., 2014;). Students who receive feedback on school work from their teachers performed well and stayed in school. In the analyses of Sabates et al. (2013) and Abhisek and Soumendu (2014) in Bangladesh and India, respectively, this implies that students may lose interest in school owing to the absence of interaction in teaching and learning. Corporal punishment too can initiate early school leaving. Some students leave school for fear of the kind of punishment they are due to receive (Ampiah \& Adu-Yeboah, 2009; Makwinja-Morara, 2009; Tukundane et al., 2014; Huisman \& Smits, 2015) (Ghana, Botswana, Uganda, 30 developing countries). In rural Pakistan, government schools have a higher dropout rate because they are of lesser quality, as compared with private schools (Lloyd et al., 2009). 


\section{Environment}

Huisman and Smits (2015) showed that dropout is less in communities where there are more adults with higher education and white-collar jobs in 30 developing countries. The result is consistent with that of Korinek and Punpuing (2012) in Thailand, who confirmed that the odds of deserting school are relatively lower in areas with a large proportion of adults employed in managerial, professional and clerical positions, and a relatively smaller proportion engaged in agriculture. In other words, the engagement of the larger population in agriculture in rural regions provides no incentives for investment in children's education given the absence of future employment possibilities (Mahlomaholo, 2012; Edwards et al., 2014; Mokibelo, 2014; Tukundane et al., 2014) (South Africa, Cambodia, Botswana, Uganda). This boils down to the assertion by Lloyd et al. (2009) and Chung and Mason (2012) in Pakistan and China, respectively, that development in a community is a statistically significant and important factor in reducing the odds of dropout.

Another aspect is bullying. Students facing the challenges of bullying from others around them are at risk of deserting school. From studies in Nigeria, Alika (2012) reported that the rate of dropout was high among students who were experiencing bullying. According to his explanation, this could be as a result of anxiety, frustration, depression and fear that emerged from bullying. Years of schooling is also reduced by the distance between a child's home and the school (Makwinja-Morara, 2009; Zhao \& Glewwe, 2010; Siddhu, 2011; Mahlomaholo, 2012; Manandhar \& Sthapit, 2012; Wudu, 2015) (Botswana, China, India, South Africa, Nepal, Ethiopia). That is, the further the distance to school, the quicker a learner will leave school. This is more pronounced for girls. In research carried out in India and Turkey by Siddhu (2011) and Tas et al. (2013), respectively, results suggested that there is fear for girls' safety generally when they leave home for school. This situation is heightened where school distances are greater.

\section{Region of residence}

The effect of this factor can be felt more by children living in the rural areas (Biddlecom et al., 2008; Smits \& Huisman, 2013; Wudu, 2015) (Burkina Faso, Ghana, Malawi, Uganda, Algeria, Egypt, Morocco, Syria, Tunisia, Yemen, Ethiopia). In Thailand, for example, the urban areas provide certain enrolment advantages such as the household and community structural factors as compared with the rural areas (Korinek \& Punpuing, 2012). This includes differences in the wealth of households, as well as the differences in the labour market structure. Agriculture predominates in the rural economy and school attrition tends to be higher, as observed by (Siddhu, 2011) in India. Coupled with the problem of school unavailability, girls in the study of the 30 developing countries in Huisman and Smits (2015) are less likely to attend school in rural areas in the absence of female teachers. In other words, the presence of more female teachers reduces children's probability to quit school. 


\section{Differences between Africa and Asia}

There are some differences between Africa and Asia in the determinants of dropout. The first determinant of dropout that showed a difference in both the quantitative and qualitative studies is migration. Migration was shown to be a problem mostly in Asia and was significant in Pakistan, Thailand and Turkey (Farid-ul-Hasnain \& Krantz, 2010; Korinek \& Punpuing, 2012; Cemalcilar \& Goksen, 2014). Secondly, ethnicity was another determinant of dropout that showed a difference. Ethnicity was found to be a significant problem only in Pakistan and Cambodia (Lloyd et al., 2009; No et al., 2012; No et al., 2016).

\section{The school dropout paradigm}

The preceding examination of school dropout provides a component of distinguishable characteristics stemming from individuals and surroundings, where early school leaving altogether is the utmost. Dimensions can be identified that can be directly manipulated to facilitate targeted intervention designs, as shown in Figure 3;

Lack of interest. In normal circumstances, the effects of having less interest in studying is evident as we observe, for instance, from reasons such as truancy, drug use and preference for wage labour. The need to disengage from school also develops because of a lack of self-esteem, early marriage, poor academic performance, examination failure, relationships with opposite sex, age at school, unsociability and conflict at school.

Absence of requirements. It is observed in the majority of the studies that lack of financial means is a sure obstacle to school completion. In detail, this is brought about mostly by limited household wealth. It is also as a result of deteriorated family situations such as illness, disability, parental absence or divorce, migration, death, non-biological household and increase in household members. Besides financial resources, some poorer areas are reported to have no available schools for students, inadequate school facilities and assistance or encouragement from school and family. Additionally, the problem of underdeveloped communities poses threats such as a lack of transportation, very long distance to school and inappropriate language of instruction and textbook content. For instance, textbooks' contents can be contextualised meaningfully only in the urban environment that has

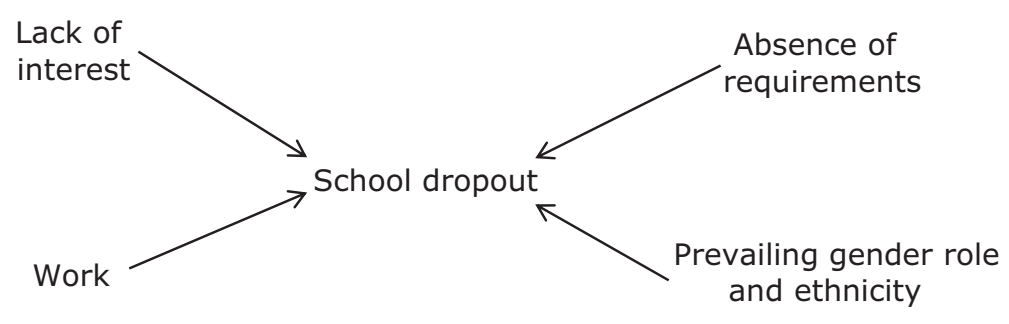

Figure 3. Framework for school dropout 
got the facilities and thus, it is not known to rural pupils. Examples of such facilities include constructions and equipment like playground, supermarket, subway, city centre, park, tower block and libraries common to mainly urban areas in the community (Chung \& Mason, 2012).

Work. Besides personal preference for wage labour, students engage themselves in wage labour because of demands from the family, where they work to assist in financial supplies. The demand for labour is also due to farming and housework. These activities keep students away from school, the contexts in which some studies mention irregular attendance and seasonal withdrawal as consequences, and eventual school dropout.

Prevailing gender role and ethnicity. On the one hand, there is the problem of some parents not being inclined to send their daughter to school. On the other hand, gender bias is a form of cultural restriction where girls are generally not supposed to go to school, for other options such as housework and early marriage. Furthermore, the existence of numerous ethnic groups can lead to disadvantageous segregation where some groups become disadvantaged minorities as a consequence of their language or religion. To that effect, most of their children drop out of school.

\section{Conclusion and policy implications}

Based on the systematic review of the literature, we can conclude that pull factors, push factors and falling out factors determine early school leaving. These pull factors include gender, religion, ethnicity, house work, wage labour, farming, region of residence, ill health, truancy, disability, pregnancy, marriage, age, no self-esteem, late school entry, pre-marital sex, substance use, family-related factors and environmental factors. The factors that push students away in these findings are inadequate school facilities and quality, unavailable and unskilled teachers, student-teacher conflict, inadequate student assistance, no leisure activities, unsuitable school time, corporal punishment, exam failure, school distance, absenteeism, grade repetition, poor academic performance and unofficial enrolment. The falling out factors are lack of interest, unawareness of importance of education and recently finished primary school.

The results suggest that the problem of dropout is multi-perspective (individual and institutional) in both Asia and Africa, involving a variety of factors that require targeting in order to encourage students to stay in school. The institutional perspective involves dropout determinants associated with the school, community and family. This is in other words, the dimensions-absence of requirements, gender role and ethnicity - previously discussed. There is a need to assess and regulate the financial expenditure faced by households to educate primary, secondary and high school students in areas where financial difficulties seem to be a major challenge. School provisions should be carefully checked to ensure that they, at least, include the basic necessities required for quality learning and skills development. These are provisions like laboratories, libraries, classrooms, trained and sufficient teachers, and sporting as well as leisure activities. It is also essential that schools are available and that students 
do not find it very difficult to commute to school or switch to another school based, for instance, on the trajectory between their home and school.

This review shows some similarities with the main dropout factors found in a study for developed countries (western world), carried out by De Witte et al. (2013). In the latter study, results suggested that the school-related factors are similar to the ones identified in this study with the exception of age, which is not prevalent in the western world. The problem of gender, though present in the developed nations, differs with that in the less developed countries in that the effect in the latter nations is related more to cultural beliefs that mostly disfavour girls. Family-wise, the factors that all the countries (i.e. both developed and less developed countries) have in common are socioeconomic status, non-biological child, family crisis, single parent and unsupportive family.

The school factors found in both worlds include school quality, facilities, teacher experience and support. Community factors such as peer influence, wage labour and neighbourhood influence are also present in all regions. School dropout in Africa and Asia, however, is more influenced by community factors including underdevelopment, distance to school, region of residence, religion and ethnicity. The overall and significant determinants are problems on a seemingly equal scale in both Africa and Asia partly owing to the existence of common beliefs in both areas, the high population involvement in less professional activities like agriculture and the lagging behind of infrastructure and educational provisions as compared with the developed world.

\section{References}

Abhisek, B. \& Soumendu, C. (2014) Status of educational performance of tribal students: A study in Paschim Medinipur District, West Bengal, Educational Research and Reviews, 9(20), 925937. https://doi.org/10.5897/err2012.220.

Abuya, B., Oketch, M. \& Musyoka, P. (2013) Why do pupils dropout when education is "free"? Explaining school dropout among the urban poor in Nairobi, Compare: A Fournal of Comparative and International Education, 43(6), 740-762. https://doi.org/10.1080/03057925.2012. 707458.

Abuya, B. A., Onsomu, E. O. \& Moore, D. (2014) Determinants of educational exclusion: Poor urban girls' experiences in- and out-of-school in Kenya, Prospects, 44(3), 381-394. https://doi. org/10.1007/s11125-014-9306-1.

Alika, H. I. (2012) Bullying as a correlate of dropout from school among adolescents in Delta State: Implication for counselling, Education, 32 (3), 523-531. Available online at: http://go.ga legroup.com/ps/anonymous?id=GALE $\% 7 \mathrm{CA} 283945587 \& \mathrm{sid}=$ googleScholar\&v=2 1 \&it=r\&li nkaccess $=$ fulltext $\&$ issn $=00131172 \& \mathrm{p}=\mathrm{AONE} \& \mathrm{sw}=\mathrm{w} \&$ authCount $=1$ \&isAnonymousEntry $=$ true (accessed 27 June 2016).

Aloise-Young, P. A. (2002) Cigarette smoking and perceived health in school dropouts: A comparison of Mexican American and non-Hispanic white adolescents, fournal of Pediatric Psychology, 27(6), 497-507. https://doi.org/10.1093/jpepsy/27.6.497.

Ampiah, J. G. \& Adu-Yeboah, C. (2009) Mapping the incidence of school dropouts: A case study of communities in Northern Ghana, Comparative Education, 45(2), 219-232. https://doi.org/ $10.1080 / 03050060902920625$.

Ananga, E. D. (2011) Typology of school dropout: The dimensions and dynamics of dropout in Ghana, International fournal of Educational Development, 31(4), 374-381. https://doi.org/10. 1016/j.ijedudev.2011.01.006. 
Anderson, A., Hamilton, R. J. \& Hattie, J. (2004) Classroom climate and motivated behaviour in secondary schools, Learning Environments Research, 7(3), 211-225. https://doi.org/10.1007/ s10984-004-3292-9.

Bah-Lalya, I. (2015) Koranic education centres: A viable educational alternative for the disadvantaged learner in Sahel Africa?, International Review of Education, 61(4), 465-479. https://doi. org/10.1007/s11159-015-9505-x.

Banik, A. \& Neogi, D. (2015) Poverty and earning compulsions for the family have pushed children out of schools, International fournal of Social Economics, 42(10), 946-958. https://doi.org/10. 1108/ijse-02-2014-0023.

Biddlecom, A., Gregory, R., Lloyd, C. B. \& Mensch, B. S. (2008) Associations between premarital sex and leaving school in four Sub-Saharan African countries, Studies in Family Planning, 39 (4), 337-350. https://doi.org/10.1111/j.1728-4465.2008.00179.x.

Braimah, I. \& Oduro-Ofori, E. (2005) Basic school dropout in Ghana: A case study of the Amansie West district, Fournal of Science and Technology, 25(1), 67-76. https://doi.org/10.4314/just. v25i1.32933.

Bronfenbrenner, U. (1977) Toward an experimental ecology of human development, American Psychologist, 32(7), 513-531. https://doi.org/10.1037//0003-066x.32.7.513.

Bronfenbrenner, U. (1979) The ecology of human development: Experiments by nature and design (Cambridge, MA, Harvard University Press).

Brown, B. A. (2010) Social hostility and the "dropout" syndrome: Leadership assisting youths' reentry into school?, Educational Review, 62(1), 53-67. https://doi.org/10.1080/ 00131910903469577.

Cemalcilar, Z. \& Gokşen, F. (2014) Inequality in social capital: Social capital, social risk and dropout in the Turkish education system, British fournal of Sociology of Education, 35(1), 94-114. https://doi.org/10.1080/01425692.2012.740807.

Chernichovsky, D. (1985) Socioeconomic and demographic aspects of school enrollment and attendance in rural Botswana, Economic Development and Cultural Change, 33(2), 319-332. https://doi.org/10.1086/451463.

Christian, M. (2015) School location, school section and students' gender as predictors to secondary school dropout rate in Rivers State, Nigeria, fournal of Education and Practice, 6(28), 113-118. Available online at: https://files.eric.ed.gov/fulltext/EJ1081234.pdf (accessed 27 June 2016).

Chung, C. \& Mason, M. (2012) Why do primary school students drop out in poor, rural China? A portrait sketched in a remote mountain village, International fournal of Educational Development, 32(4), 537-545. https://doi.org/10.1016/j.ijedudev.2012.02.012.

De Witte, K., Cabus, S., Thyssen, G., Groot, W. \& Van den Brink, H. M. (2013) A critical review of the literature on school dropout, Educational Research Review, 10, 13-28. https://doi.org/10. 1016/j.edurev.2013.05.002.

Diyu, X. (2001) Investigation and discussion on the problem of primary and secondary school dropouts in poor areas, Chinese Education and Society, 34(5), 49-58. https://doi.org/10.2753/ ced1061-1932340549.

Doll, J. J., Eslami, Z. \& Walters, L. (2013) Understanding why students drop out of high school, according to their own reports: Are they pushed or pulled, or do they fall out? A Comparative Analysis of Seven Nationally Representative Studies, SAGE Open, 3(4). https://doi.org/10. 1177/2158244013503834.

Dorman, J. P., Fraser, B. J. \& McRobbie, C. J. (1997) Relationship between school-level and classroom-level environments in secondary schools, fournal of Educational Administration, 35(1), 74-91. https://doi.org/10.1108/09578239710156999.

Edwards, D. B., Zimmermann, T., Sitha, C., Williams, J. H. \& Kitamura, Y. (2014) Student transition from primary to lower secondary school in Cambodia: Narrative insights into complex systems, Prospects, 44(3), 367-380. https://doi.org/10.1007/s11125-014-9318-x.

Farid-ul-Hasnain, S. \& Krantz, G. (2010) Assessing reasons for school/college dropout among young adults and implications for awareness about STDs and HIV/AIDS: Findings from a 
population-based study in Karachi, Pakistan, International fournal of Behavioral Medicine, 18 (2), 122-130. https://doi.org/10.1007/s12529-010-9074-0.

Finn, J. D. (1989) Withdrawing from school, Review of Educational Research, 59(2), 117-142. https://doi.org/10.2307/1170412.

Flisher, A. J., Townsend, L., Chikobvu, P., Lombard, C. F. \& King, G. (2010) Substance use and psychosocial predictors of high school dropout in Cape Town, South Africa, Fournal of Research on Adolescence, 20(1), 237-255. https://doi.org/10.1111/j.1532-7795.2009.00634.x.

Fortin, L., Marcotte, D., Diallo, T., Potvin, P. \& Royer, É. (2013) A multidimensional model of school dropout from an 8-year longitudinal study in a general high school population, European Fournal of Psychology of Education, 28(2), 563-583. https://doi.org/10.1007/s10212-012-0129-2.

Fredricks, J. A., Blumenfeld, P. C. \& Paris, A. H. (2004) School engagement: Potential of the concept, state of the evidence, Review of Educational Research, 28(2), 563-583. https://doi.org/10. 3102/00346543074001059.

Fredriksen, K. \& Rhodes, J. (2004) The role of teacher relationships in the lives of students, New Directions for Youth Development, 2004(103), 45-54. https://doi.org/10.1002/yd.90.

Guryan, J. (2004) Desegregation and black dropout rates, American Economic Review, 94(4), 919943. https://doi.org/10.1257/0002828042002679.

Hanushek, E. A., Lavy, V. \& Hitomi, K. (2008) Do students care about school quality? Determinants of dropout behavior in developing countries, fournal of Human Capital, 2(1), 69-105. https://doi.org/10.1086/529446.

Holmes, J. (2003) Measuring the determinants of school completion in Pakistan: Analysis of censoring and selection bias, Economics of Education Review, 22(3), 249-264. https://doi.org/10. 1016/s0272-7757(02)00024-9.

Huisman, J. \& Smits, J. (2015) Keeping children in school: Effects of household and context characteristics on school dropout in 363 districts of 30 developing countries, SAGE Open, 5(4). https://doi.org/10.1177/2158244015609666.

Igboanusi, H. (2014) The English-only language education policy in The Gambia and low literacy rates, International fournal of Bilingual Education and Bilingualism, 17(5), 558-569. https://doi. org/10.1080/13670050.2013.851642.

Korinek, K. \& Punpuing, S. (2012) The effect of household and community on school attrition: An analysis of Thai youth, Comparative Education Review, 56(3), 474-510. https://doi.org/10. $1086 / 666911$.

Lamb, S. \& Markussen, E. (2011) School dropout and completion: An international perspective, in: S. Lamb, E. Markussen, R. Teese, N. Sandberg, \& J. Polesel (Eds) School dropout and completion (Dordrecht, Springer), 1-18. https://doi.org/10.1007/978-90-481-9763-7_1

Levy, M. B. (1971) Determinants of primary school dropouts in developing countries, Comparative Education Review, 15(1), 44-58. https://doi.org/10.1086/445512.

Lewin, K. M. \& Little, A. W. (2011) Access to education revisited: Equity, drop out and transitions to secondary school in South Asia and Sub-Saharan Africa, International fournal of Educational Development, 31(4), 333-337. https://doi.org/10.1016/j.ijedudev.2011.01.011.

Lloyd, C. B., Mensch, B. S. \& Clark, W. H. (2000) The effects of primary school quality on school dropout among Kenyan girls and boys, Comparative Education Review, 44(2), 113-147. https://doi.org/10.1086/447600.

Lloyd, C. B., Mete, C. \& Grant, M. J. (2009) The implications of changing educational and family circumstances for children's grade progression in rural Pakistan: 1997-2004, Economics of Education Review, 28(1), 152-160. https://doi.org/10.1016/j.econedurev.2007.04.005.

Lloyd, C. B., Mete, C. \& Sathar, Z. A. (2005) The effect of gender differences in primary school access, type, and quality on the decision to enroll in rural Pakistan, Economic Development and Cultural Change, 53(3), 685-710. https://doi.org/10.1086/427042.

Lu, M., Cui, M., Shi, Y., Chang, F., Mo, D., Rozelle, S. \& Johnson, N. (2016) Who drops out from primary schools in China? Evidence from minority-concentrated rural areas, Asia Pacific Education Review, 17(2), 235-252. https://doi.org/10.1007/s12564-016-9421-1.

Mahlomaholo, S. M. (2012) Early school leavers and sustainable learning environments in rural contexts, Perspectives in Education, 30(1), 101-110. Available online at: http://scholar.ufs.ac.za: 
8080/xmlui/bitstream/handle/11660/3009/persed_v30_n1_a12.pdf?sequence=1 (accessed 26 May 2016).

Makwinja-Morara, V. (2009) Female dropouts in Botswana junior secondary schools, Educational Studies, 45(5), 440-462. https://doi.org/10.1080/00131940903190493.

Manandhar, N. \& Sthapit, A. (2012) Determinants of primary school dropout in Nawalparasi District, Fournal of College of Medical Sciences, 6(4), 14-18. https://doi.org/10.3126/jcmsn.v6i4. 6720 .

Mokibelo, E. B. (2014) Why we drop out of school: Voices of San School dropouts in Botswana, The Australian fournal of Indigenous Education, 43(2), 185-194. https://doi.org/10.1017/jie.2014.26.

Morrison, G. M., Robertson, L., Laurie, B. \& Kelly, J. (2002) Protective factors related to antisocial behavior trajectories, fournal of Clinical Psychology, 58(3), 277-290. https://doi.org/10.1002/ jclp.10022.

Mzuza, M. K., Yudong, Y. \& Kapute, F. (2014) Analysis of factors causing poor passing rates and high dropout rates among primary school girls in Malawi, World fournal of Education, 4(1), 48. https://doi.org/10.5430/wje.v4n1p48.

Newcomb, M. D., Abbott, R. D., Catalano, R. F., Hawkins, J. D., Battin-Pearson, S. \& Hill, K. (2002) Mediational and deviance theories of late high school failure: Process roles of structural strains, academic competence, and general versus specific problem behavior, fournal of Counseling Psychology, 49(2), 172. https://doi.org/10.1037//0022-0167.49.2.172.

No, F., Sam, C. \& Hirakawa, Y. (2012) Revisiting primary school dropout in rural Cambodia, Asia Pacific Education Review, 13(4), 573-581. https://doi.org/10.1007/s12564-012-9220-2.

No, F., Taniguchi, K. \& Hirakawa, Y. (2016) School dropout at the basic education level in rural Cambodia: Identifying its causes through longitudinal survival analysis, International fournal of Educational Development, 49, 215-224. https://doi.org/10.1016/j.ijedudev.2016.03.001.

Pintrich, P. R. \& De Groot, E. V. (1990) Motivational and self-regulated learning components of classroom academic performance, fournal of Educational Psychology, 82(1), 33. https://doi.org/ 10.1037//0022-0663.82.1.33.

Polat, S. (2014) Reasons for school dropout in vocational high school, Educational Research and Reviews, 9(18), 711-718. https://doi.org/10.5897/err2014.1830.

Ream, R. K. \& Rumberger, R. W. (2008) Student engagement, peer social capital, and school dropout among Mexican American and non-Latino white students, Sociology of Education, 81(2), 109-139. https://doi.org/10.1177/003804070808100201.

Rumberger, R. W. (1995) Dropping out of middle school: A multilevel analysis of students and schools, American Educational Research fournal, 32(3), 583-625. https://doi.org/10.3102/ 00028312032003583.

Sabates, R., Hossain, A. \& Lewin, K. M. (2013) School drop out in Bangladesh: Insights using panel data, International fournal of Educational Development, 33(3), 225-232. https://doi.org/10. 1016/j.ijedudev.2012.09.007.

Sahin, S., Arseven, Z. \& Kilic, A. (2016) Causes of student absenteeism and school dropouts, International Fournal of Instruction, 9(1), 195-210. https://doi.org/10.12973/iji.2016.9115a.

Sarker, P. \& Davey, G. (2009) Exclusion of indigenous children from primary education in the Rajshahi Division of northwestern Bangladesh, International fournal of Inclusive Education, 13(1), 1-11. https://doi.org/10.1080/13603110701201775.

Shahidul, S. M. (2013) Household decision-making process: It's effect on school dropout behavior for girls in the secondary school level in Bangladesh, International Education Studies, 6(1), 132141. https://doi.org/10.5539/ies.v6n1p132

Shi, Y., Zhang, L., Ma, Y., Yi, H., Liu, C., Johnson, N., Chu, J., Loyalka, P. \& Rozelle, S. (2015) Dropping out of rural China's secondary schools: A mixed-methods analysis, The China Quarterly, 224, 1048-1069. https://doi.org/10.1017/s0305741015001277.

Siddhu, G. (2011) Who makes it to secondary school? Determinants of transition to secondary schools in rural India, International fournal of Educational Development, 31(4), 394-401. https://doi.org/10.1016/j.ijedudev.2011.01.008. 
Skinner, E. A. \& Pitzer, J. (2012) Developmental dynamics of engagement, coping, and everyday resilience, in: S. L. Christenson, A. L. Reschly \& C. Wylie (Eds) Handbook of research on student engagement. (New York, Springer Science), 21-24.

Smits, J. \& Huisman, J. (2013) Determinants of educational participation and gender differences in education in six Arab countries, Acta Sociologica, 56(4), 325-346. https://doi.org/10.1177/ 0001699313496259.

Staff, J. \& Kreager, D. A. (2008) Too cool for school? Violence, peer status and high school dropout, Social Forces, 87(1), 445-471. https://doi.org/10.1353/sof.0.0068.

Tansel, A. (2002) Determinants of school attainment of boys and girls in Turkey: Individual, household and community factors, Economics of Education Review, 21(5), 455-470. https://doi. org/10.1016/s0272-7757(01)00028-0.

Tas, A., Bora, V., Selvitopu, A. \& Demirkaya, Y. (2013) Reasons for dropout for vocational high school students, Educational Sciences: Theory and Practice, 13(3), 1561-1565. https://doi.org/ 10.12738/estp.2013.3.1398.

Thomas, D., Beegle, K., Frankenberg, E., Sikoki, B., Strauss, J. \& Teruel, G. (2004) Education in a crisis, Fournal of Development Economics, 74(1), 53-85. Available online at: http://escholar ship.org/uc/item/1gh9r6rr\#page-5 (accessed 25 May 2016).

Tukundane, C., Minnaert, A., Zeelen, J. \& Kanyandago, P. (2015) A review of enabling factors in support intervention programmes for early school leavers: What are the implications for SubSaharan Africa?, Children and Youth Services Review, 52, 54-62. https://doi.org/10.1016/j.childy outh.2015.02.011.

Tukundane, C., Zeelen, J., Minnaert, A. \& Kanyandago, P. (2014) 'I felt very bad, I had self-rejection': Narratives of exclusion and marginalisation among early school leavers in Uganda, fournal of Youth Studies, 17(4), 475-491. https://doi.org/10.1080/13676261.2013.830703.

Ud Din, M. N., Dad, H., Iqbal, J., Ali Shah, S. S. \& Niazi, M. I. (2011) Causes of male dropout rate in Pakistan, Fournal of College Teaching and Learning, 8(4), 37-42. https://doi.org/10. 19030/tlc.v8i4.4198.

UNESCO (2015). EFA Global Monitoring Report. Education for all 2000-2015: Achievements and challenges (Paris, UNESCO). Available online at: http://unesdoc.unesco.org/images/0023/ 002322/232205e.pdf/ (accessed 27 June 2016).

UNESCO Institute for Statistics (2009) Education indicators: Technical guidelines (Paris, UNESCO). Available online at: http://www.uis.unesco.org/Library/Documents/eiguide09-en.pdf/ (accessed 25 May 2016).

UNESCO Institute for Statistics (2017) Education (Paris, UNESCO). Available online at: http://da ta.uis.unesco.org/Index.aspx?DataSetCode=EDULIT_DS\#/(accessed 25 May 2016).

United Nations (2014) The millennium development goals 2014 (New York, United Nations). Available online at: http://www.un.org/millenniumgoals/2014\%20MDG\%20report/MDG\% 202014\%20English\%20web.pdf/ (accessed 25 May 2016).

Wang, M.-T. \& Fredricks, J. A. (2014) The reciprocal links between school engagement, youth problem behaviors, and school dropout during adolescence, Child Development, 85(2), 722 737. https://doi.org/10.1111/cdev.12138.

Wegner, L., Flisher, A. J., Chikobvu, P., Lombard, C. \& King, G. (2008) Leisure boredom and high school dropout in Cape Town, South Africa, Fournal of Adolescence, 31(3), 421-431. https://doi.org/10.1016/j.adolescence.2007.09.004.

Werblow, J. \& Duesbery, L. (2009) The impact of high school size on math achievement and dropout rate, The High School fournal, 92(3), 14-23. https://doi.org/10.1353/hsj.0.0022.

Wudu, M. T. (2015) Challenges students face in their transition from primary to secondary school and the interventions schools take to ease the transition, Educational Research and Reviews, 10 (5), 622-633. https://doi.org/10.5897/err2014.2055.

Yi, H., Zhang, L., Luo, R., Shi, Y., Mo, D., Chen, X., Brinton, C. \& Rozelle, S. (2012) Dropping out: Why are students leaving junior high in China's poor rural areas?, International Fournal of Educational Development, 32(4), 555-563. https://doi.org/10.1016/j.ijedude v.2011.09.002. 
Zhao, M. \& Glewwe, P. (2010) What determines basic school attainment in developing countries? Evidence from rural China, Economics of Education Review, 29(3), 451-460. https://doi.org/10. 1016/j.econedurev.2009.10.008.

Zuilkowski, S. S., Jukes, M. C. H. \& Dubeck, M. M. (2016) 'I failed, no matter how hard I tried': A mixed-methods study of the role of achievement in primary school dropout in rural Kenya, International Fournal of Educational Development, 50, 100-107. https://doi.org/10.1016/j.ijedude v.2016.07.002.

\section{SUPPORTING INFORMATION}

Additional supporting information may be found online in the Supporting Information section at the end of the article:

Table S1: Overview of the School Dropout Determinants Included in the Review: Quantitative Studies

Table S2: Overview of the School Dropout Determinants Included in the Review: Mixed Studies

Table S3: Overview of the School Dropout Determinants Included in the Review: Qualitative Studies 